\title{
Interpreting and appropriating texts in the history of political thought: Quentin Skinner and poststructuralism
}

\author{
Tony Burns \\ School of Politics \& International Relations, University of Nottingham, University Park, \\ Nottingham, NG7 2RD, UK. \\ tony.burns@nottingham.ac.uk
}

\begin{abstract}
This article argues that for purposes of hermeneutics, in relation to texts in the history of political thought, it is fruitful to make a conceptual distinction between the idea of a 'reading', an 'interpretation' and an 'appropriation' of a text. The article relates these ideas to two basic approaches to hermeneutic understanding, that of Quentin Skinner, on the one hand, and that associated with the philosophy of poststructuralism on the other. It is argued that once the above conceptual distinctions have been made it can be demonstrated that these two approaches to hermeneutic understanding are not necessarily incompatible with one another. It is also argued that Skinner came to appreciate that this is the case in the later 1980s, and that this constituted a significant revision of the methodological position views which Skinner had advocated before that time, from the late 1960s onwards.
\end{abstract}

Contemporary Political Theory (2011) 10, 313-331. doi:10.1057/cpt.2010.25

Keywords: Quentin Skinner; poststructuralism; postmodernism; history of political thought; hermeneutics; interpretivism

The hermeneutic approaches of Quentin Skinner and those of poststructuralist philosophy are often thought to be diametrically opposed to one another. I propose to challenge this view. According to the first of these approaches, the meaning of a text is something which lies within a text and is discovered or recovered by the person who reads it (Tully, 1988; Skinner, 2002a-d). On this view, the meaning of a text is something which is created by its author and given to a text in the process of writing it. Advocates of this view subscribe to the principle of 'authorial intentionalism'. Those who endorse this approach assume that this process of creating meaning and giving it to a text is carried out intentionally, and that the authors of texts have full self-conscious awareness of (and control over) their own intentions, and hence also the meaning of the texts they produce. This is an approach, therefore, which 
privileges the standpoint of the author of a text. It insists that those who are seeking to understand a text cannot afford to ignore the intentions of its author when writing it. If this is not sufficient, it is at least a necessary condition for the success of the hermeneutic enterprise.

According to the conventional view of poststructuralism, on the other hand, the meaning of a text is created by and given to a text, not by its author, but solely and exclusively by the readers of it (Norris, 1987, pp. 109-12, 219; Wood, 1987, pp. 176-77; Abrams, 1991, pp. 121, 124; Cook, 1991, p. 111; Burke, 2008, pp. 134-35). As James Risser has put it, if a more traditional hermeneutics thinks that its task is to 'decipher meaning', which is assumed to be 'something that is secretly there' in a text, and thus 'something to be sought out by interpretation', for those who adopt this alternative approach the text 'remains open to a fundamental multiplicity of meaning, which, for all intents and purpose, must be produced' by the reader (Risser, 1991, pp. 93-94). This way of thinking about hermeneutics, together with the principle of 'the death of the author' with which it is so usually associated, is often attributed to poststructuralist philosophers such as Michel Foucault, Gilles Deleuze and Jacques Derrida (Burke, 2008 [1992]; also Barthes, 1977; Foucault, 1984). As Skinner has observed, this approach is associated with the view that, just as in natural science, so also in philosophical hermeneutics, 'anything goes!' (Feyerabend, 1975, pp. 23, 28; Skinner, 1985, p. 7). Like Feyerabend's philosophy of science, it is 'anarchist' in spirit.

My argument is that to think of Skinner's methodology and that of poststructuralism as being diametrically opposed to one another is to exaggerate the significance of the differences which exist between them. This way of thinking is misleading and does not do justice either to Skinner or to poststructuralism.

\section{Readings, Interpretations and Appropriations of Texts}

In this section, I introduce the terminology used in the rest of the article. I characterize the two approaches to hermeneutic understanding referred to above by employing the notions of a 'reading', an 'interpretation' and an 'appropriation' of a text. Most commentators think that hermeneutic understanding has to do with the interpretation of texts. Where I employ the term 'reading', they employ the term 'interpretation'; or alternatively they employ these two terms interchangeably. The notion of a reading and that of an interpretation are thus considered to be synonymous in meaning. No distinction is made between these two notions, and it is not thought that much turns on the issue of which of them is employed. I, on the other hand, consider this distinction to be theoretically significant. It helps us to understand better the relationship, 
which exists between the views of Skinner and those of poststructuralists. Before proceeding, therefore, it is necessary to say more about these concepts.

The first concept, that of a reading, is the most general of the three and operates at a higher level than the other two, which must be thought of as operating on the same level as one another. In other words, interpretations and appropriations are both readings of texts. The category of 'reading' is the genus of which 'interpretation' and 'appropriation' are two of the species. By a reading I have in mind what is usually meant by the word 'interpretation'. A reading is an attempt by someone to understand a text, it being assumed that the text in question can be, and often will be, understood in different ways. A reading may pay attention to the intentions of the authors of texts, or to the meaning which texts, and the ideas which they contain, have for the persons who wrote them, but it does not have to do so. A reading which fails to do this does not, thereby, lose its authenticity as a reading.

A reading is an attempt to 'make sense of' a text. However, this expression is deliberately ambiguous in meaning, and allows for the possibility that different readers might attempt to make sense of the same text in different ways. For example, the expression might relate to an effort to discover some meaning, which is assumed to be already there in a particular text. On the other hand, however, it might have to do with an effort to give a certain meaning to a text, or to impose a certain meaning or upon it. These are quite different types of activity, but both of them could be said to fall under the notion of reading, as it is used here. This use of the word is broad enough to allow any account of a particular text to be considered as a possible or plausible reading of it. It makes no sense, on this view, to talk about the misreading of any text. This is the crucial difference between a reading and an interpretation of a text.

By an 'interpretation' I mean a certain type of reading. Readings of this kind are associated with the first approach to hermeneutic understanding referred to above. Interpretations aim to get at something which is assumed by the interpreter to lie within the text itself. This 'something' is assumed to be the meaning of the text in question. To interpret a text, on this view, is to attempt to recover or perhaps discover the meaning of a text, and this attempt may or may not be successful. Someone who offers an interpretation of a text can be thought of as seeking the 'truth' about its meaning. It is assumed that readings which are also interpretations can be either true or false, correct or incorrect. At least it is assumed that they can be assessed as being either closer to or further away from the true or correct account of the meaning of a text. In principle, therefore, competing interpretations of texts can be evaluated on the basis of an appeal to relevant empirical evidence and disputes between interpreters might be resolved by rational argument and debate. If we think about the notion of interpretation in this way then it does make sense to talk about the misinterpretation of texts, even if we cannot talk about the 
misreading of them. This approach to the reading of texts may be associated with the writings of Quentin Skinner, although Skinner does not himself employ this terminology. At times Skinner has given the impression that in his view the only legitimate way to read a text is to interpret it.

It might be thought that this usage of the word 'interpretation' is an unusual one, as this notion is usually associated with the principle of relativism or perspectivism, and hence with the view that all interpretations are equally valid. This view is widely held in the recent literature, which discusses the 'interpretivist' approach in the discipline of politics. For instance, David Marsh and Paul Furlong have claimed that researchers working within the 'interpretist' tradition 'rarely accept any notion of objectivity' (Marsh and Furlong, 2002 [1995], p. 22). In their view, it is unusual to find an advocate of any kind of interpretive approach who is not a relativist. One example of this attitude is the work of Chris Clarke, who associates interpretivism with 'scepticism towards claims to objectivity' (Clarke, 2009, p. 32). According to Clarke, interpretivism is associated with, first, 'the conviction that the world can be viewed from a multiplicity of perspectives' and, second, the 'normative commitment' that all of these different perspectives ought to be accorded 'equal respect' (Clarke, 2009, p. 32). In Clarke's opinion, interpretivism is in consequence 'drawn inevitably towards a suspicion of all epistemological foundations', and hence also towards a commitment to epistemic relativism (Clarke, 2009, p. 32). However, it is not clear to me that it is so rare to find hermeneuticists who are objectivists and not relativists. For example, both E.D. Hirsch jr. and Quentin Skinner reject the principle of relativism (Hirsch, 1967, 1976; Skinner, 1985). Indeed, Skinner has maintained that 'grasping an alien action, utterance or text "objectively" in its own terms' is 'the traditional goal' of all 'interpretation' (Skinner, 1985, p. 7). Skinner has claimed that interpretation is traditionally considered to be a 'method of attaining truths', that is to say, objective truths relating to the meaning of texts (Skinner, 1985, p. 7). It is far from clear, then, that all advocates of hermeneutics are epistemic relativists.

Nietzsche's claim that 'there are no facts, only interpretations' is commonly associated with interpretivism today, both by interpretivists themselves and by its critics (Nietzsche, 1968, p. 267). On what is allegedly Nietzsche's view, the idea of a 'factual interpretation' or an interpretation which might be said to be, if not objectively true, then at least an attempt to get at an objective truth, or the truth relating to the meaning of a text, a truth which subsists in some way independently of the reader (who does not therefore create it), is a contradiction in terms. According to the meaning of the term 'interpretation' as it is used here, however, this is precisely what an interpretation, in the strict sense of the term, attempts to do. Perhaps the best way to think about this is to employ an analogy taken from the discipline of medicine. The images on an $\mathrm{X}$-ray photograph, or the symptoms of a disease, do not speak for themselves.

316 (C) 2011 Macmillan Publishers Ltd. 1470-8914 Contemporary Political Theory Vol. 10, 3, 313-331 
They do not directly and transparently indicate which disease it is that they are the symptoms of. They require interpretation. Different doctors, depending on their experience, might interpret these images or symptoms in different ways. But these interpretations are not all equally valid, or equally true. Mistakes can be made, wrong diagnoses offered, and so on. This is the sense in which the word 'interpretation' is being employed in this article. Those familiar with Michel Foucault's views regarding the nature of 'the medical gaze' will appreciate that the view offered here rests upon different assumptions (Foucault, 1993 [1963], pp. x, xii, xviii, 38-39, 54, 89-90, 107-108, 136-137).

I now turn to consider the concept of appropriation. This concept has a part to play in the hermeneutics of Paul Ricoeur (Ricoeur, 1976, pp. 43-44, 91-94; 1981). Here, however, I employ the term differently. I associate the idea of appropriation with the second approach to hermeneutic understanding referred to earlier. Unlike an interpretation, an appropriation is a selective reading of a text. Readings of this kind have a practical relevance for the reader, although there are many different reasons why this might be the case, not all of which would be considered to be 'serious' by some commentators. For example, the purpose of offering an appropriation of a text might be to persuade somebody to act in a certain way, to amuse or entertain them, to provoke a certain response in them and so on. In readings of this kind the ideas of the author of a text are taken up by appropriators and used by them for purposes of their own. Such readings reflect the interest and concerns of the appropriator and not those of the author. Those who appropriate texts are willing to plunder them for ideas which they find useful, and to present those ideas to the world, either in their own name, or in the name of the author of the text in question, thereby appealing to that author's authority, even if at the same time they distort the meaning of these ideas by ignoring the way in which they were used and understood by the author. Appropriators have no interest in the intentions of the author, or the meaning which a text has for the person who wrote it. Nor are they interested in the 'truth'. Their readings are so cavalier, that is to say, biased, partial, selective, unbalanced, one-sided, that it would be incorrect to call them interpretations of the text in question in the sense of the term outlined earlier. The person who appropriates a text makes no effort at all to offer an interpretation of it. Given that this is so, for advocates of appropriation it makes no sense to say that there is only one reading of a text, which might be said to be legitimate or valid. There can be no misappropriations of a text.

Referring again to the sketch of the poststructuralist approach to hermeneutics outlined above, we may now say that, according to those who think in this way, poststructuralists are appropriators and not interpreters of texts. Indeed, on this account of their views, poststructuralists deny that interpretation is possible. Thus, echoing Nietzsche's remark that 'there are no facts, only interpretations', according to this account poststructuralists, maintain that 'there are no interpretations, only appropriations'. 
The distinction between those who interpret and those who appropriate texts is not intended as a criticism of the latter. There is more than one legitimate way to read a text. To employ the terminology of Wayne Booth, any approach to the reading of texts which suggests that either interpretation on the one hand or appropriation on the other is the only way to read a text is unjustifiably exclusive or 'monist' (Booth, 1979; Abrams, 1991, p. 398). Interpreting and appropriating texts (together with the study of both interpretations and appropriations by intellectual historians) are two separate and mutually compatible activities, neither one of which should be thought of as being superior to the other. Nor need historians of ideas take the view that their only task is to assess the validity of different interpretations of texts. They can take a legitimate interest in appropriations also.

Because interpretation and appropriation are two quite different activities, they ought to be kept conceptually separate from one another. It must be conceded, however, that in practice it might be difficult to establish whether a reading of a text is an invalid interpretation of it, on the one hand, or an appropriation of it on the other. Nevertheless, I am reluctant to accept the view, wrongly associated with poststructuralism, that there are no interpretations of texts at all and that all readings of texts are appropriations of them, either open or disguised. In my view, it is possible in principle to distinguish between interpretations and appropriations. I also think that readers of texts should be clear which of these activities they are intending to perform. In particular they should not deliberately present what they know to be appropriations of texts as if they were interpretations of them. I agree with E.D. Hirsch jr's suggestion that there is something 'wrong' about this, ethically as well as methodologically speaking (Hirsch, 1967, p. 91). I should perhaps add at this point that I consider my own task in the present article to be the interpretation of texts.

In the remainder of the article, deploying the terminology above, I consider the relationship, which exists between the views of a selection of philosophers who are commonly thought to be 'poststructuralists' and those of Quentin Skinner. I attempt to show that just as the first approach to hermeneutic understanding referred to above cannot be connected straightforwardly to the work of Skinner, so also the second cannot be connected unequivocally to poststructuralism. I shall deal with these issues in reverse order, starting with the issue of whether poststructuralist philosophers are indeed advocates, solely and exclusively, of the principle of appropriation.

\section{Poststructuralism and the Appropriation of Texts}

The poststructuralist approach to hermeneutic understanding is usually associated with the appropriation rather than the interpretation of texts. According to this view, poststructuralists do maintain that there are no interpretations, only 
appropriations'. In this section, I shall argue that although there is at least some evidence which supports this interpretation of poststructuralism, there is also evidence which counts against it, at least in the case of the work of Michel Foucault and Gilles Deleuze. When discussing the work of Nietzsche in 1977, Foucault made the following oft-cited remark: 'Nietzsche's contemporary presence is increasingly important. But I am tired of people studying [Nietzsche] only to produce the same kind of commentaries that are written of Hegel and Mallarme. For myself, I prefer to utilize the writers I like. The only valid tribute to thought such as Nietzsche's is precisely to use it, to deform it, to make it groan and protest. And if commentators say that I am being unfaithful to Nietzsche, that is of absolutely no interest' (Foucault, 1977, pp. 53-54).

Arguing in a similar way, Deleuze has asserted that, when reading texts, he sees himself 'as taking an author from behind, and giving him a child that would be his own offspring, yet monstrous. It was really important for it to be his own child, because the author had to actually say all I had him saying. But the child was bound to be monstrous too because it resulted from all sorts of shifting, slipping, dislocations, and hidden emissions that I really enjoyed' (Deleuze, 1995, p. 6; see also Zizek, 2004, pp. 45-55; Boundas, 2005). ${ }^{1}$ As Slavoj Zizek has put it, when reading texts, especially those written by someone who he perceives to be an 'enemy', Deleuze 'tries to enter the enemy's territory and twist, for his own ends' the ideas which can be found within them (Zizek, 2004, p. 46). To illustrate this point, Zizek refers to the reading of Plato which Deleuze offers in his Logic of Sense, a reading which according to Zizek 'almost makes out of Plato the first anti-Platonist' (Deleuze, 1990; Zizek, 2004, p. 46). An even better illustration, perhaps, is Deleuze's reading of Hegel. As Zizek observes, when reading Hegel Deleuze again 'twists for his own ends' the ideas of 'the very philosopher who should be his greatest enemy' (Zizek, 2004, p. 46).

These remarks do support the conclusion that both Foucault and Deleuze saw themselves as appropriators and not interpreters of texts. However, to say that is one thing. To say that they thought that interpretation is not possible is quite another. So let us now consider whether Foucault and Deleuze did hold the view that all readings are appropriations, either open or disguised. In my opinion they did not. Neither Foucault nor Deleuze reject outright the possibility of interpretation. For example, in the passage cited above Foucault accepts that his own reading of Nietzsche, in which he claims to put Nietzsche's philosophy 'to use', does indeed 'deform' that philosophy. Similarly, in the passage from Deleuze it is conceded by Deleuze that although his readings of literary texts do attribute certain views to their authors, and can therefore in some sense be said to be the 'offspring' of the literary activity of those same authors, nevertheless this offspring might justifiably on occasion be said to be 'monstrous', or again deformed. As in the case of Foucault then, so also in that of Deleuze, it is conceded that it is possible for us to differentiate between 
readings of texts which are 'deformed' and those which are not. This is hardly the attitude of someone who believes that 'anything goes' so far as the interpretation of texts is concerned.

Neither Foucault nor Deleuze distinguish between 'readings', 'interpretations' and 'appropriations' of texts. Nevertheless, both of them might be said to be enthusiasts for the activity of appropriation, precisely because they take the view that when reading a text 'anything goes'. It is arguable however, that neither of them was of the opinion that 'all readings are appropriations', that is to say that 'all alleged 'interpretations' are really or necessarily 'appropriations' open or disguised'. Both Foucault and Deleuze accepted that it is possible to distinguish between a reading of a text which is a 'deformation' of it and one which is not. They accepted therefore that it is possible to differentiate between what I have called an 'interpretation' of a text and an 'appropriation' of it. Neither of them denied that it is possible to interpret literary texts, in the sense in which the word 'interpretation' is used here. It is not so much that Foucault and Deleuze denied that interpretation in this sense is possible. It is simply that they were not interested in the interpretation of texts. They claimed the right to do something else with texts, namely read them selectively in the light of their own interest and concerns, in short to appropriate them. They did not want to supplant or completely replace the notion of interpretation by that of appropriation. Their aim was the much more limited one of having appropriation accepted as a legitimate activity alongside of (not instead of) interpretation. It is arguable, then, that both Foucault and Deleuze accepted that there is more than one way to read a text. Their approach to hermeneutic understanding was not a monist but a dualist one.

\section{Quentin Skinner's First Engagement with Poststructuralism}

The above remarks indicate that at least some poststructuralist philosophers were not as hostile to Quentin's Skinner's more traditional approach to the reading of texts as they are often thought to be. They do not reject out of hand the notion of interpretation outlined earlier. However something similar, although 'in reverse' as it were, might also be said about Skinner. On closer examination, Skinner's writings also indicate a willingness to make concessions in the light of the views advanced by his poststructuralist opponents. There are times when Skinner suggests (without of course employing the terminology) that what I have referred to as appropriation is a legitimate way to read texts, alongside of interpretation, although in his view it must not be confused with, much less identified with interpretation. There is at least some evidence that Skinner's methodological approach also is a dualist and not a monist one.

320 (C) 2011 Macmillan Publishers Ltd. 1470-8914 Contemporary Political Theory Vol. 10, 3, 313-331 
In the remainder of the article, I shall consider what Skinner has to say about poststructuralism and how this helps us to understand his own views in relation to those of poststructuralists. Over the last two or three decades Skinner on occasion discussed poststructuralist philosophy, if only briefly, in his writings. Three sources in particular are significant here. The first is Skinner's Introduction to The Return of Grand Theory in the Human Sciences, an edited collection devoted to an examination of the ideas of Foucault, Derrida others which Skinner published in 1985 (Skinner, 1985, pp. 7-8). The second is a text entitled 'A Reply to My Critics', which was first published in a volume devoted to Skinner's methodology work edited by James Tully in 1998 (Skinner, 1988, pp. 272, 276, 281-282, 338 fns 170-171). The third is his Regarding Method, the first of the three volumes of Visions of Politics, published in 2002 (Skinner, 2002c, pp. 90-93; 2002d, pp. 117-118, 120-122). An examination of these three sources suggests that Skinner's understanding of and attitude towards poststructuralism has changed over time and that this change occurred roughly around the mid 1980s. In effect, Skinner has put forward two accounts of poststructuralism which, although they are similar in some respects, nevertheless are also significantly different in others. The first of these is introduced in The Return of Grand Theory in 1985. The second is introduced in Skinner's 'Reply to my Critics' in 1988 and can also be found in Regarding Method 15 years later. In this section, I shall focus on what Skinner has to say about poststructuralism in The Return of Grand Theory.

In his initial engagement with poststructuralism Skinner claimed that, according to poststructuralist philosophers, when reading texts 'we ought not to think of interpretation as a method of attaining truths' about their meaning (Skinner, 1985, p. 7). He also argued that poststructuralism is 'unsettling' because of its 'refusal' of the idea that in matters of 'literary interpretation' the aim of recovering 'an intended meaning' by an author is 'any part of the interpreter's task' (Skinner, 1985, pp. 7-8). Noting the affinity, referred to earlier, between the poststructuralist approach to the reading of texts and the work of Paul Feyerabend, Skinner suggested that the poststructuralist approach can be summarized by saying that, like Feyerabend's 'anarchistic' philosophy of science, it too claims to be 'against method' (Skinner, 1985, p. 7). Thus poststructuralism can indeed be associated with the view that when interpreting literary texts 'anything goes!' As Skinner also noted, poststructuralism is connected to the idea of 'the death of the author,' or the view that the intentions of the author are (allegedly) irrelevant to the attempt to discover the meaning of a text (Skinner, 1988, p. 276; 2002c, pp. 90-93; 2002d, pp. 117-118, 120-122). Although Skinner does say different things about poststructuralism at different times, nevertheless this idea of 'the death of the author' is one which he has consistently associated with poststructuralism since the mid-1980s. It is a common element which is shared by his two accounts of poststructuralism.

(C) 2011 Macmillan Publishers Ltd. 1470-8914 Contemporary Political Theory Vol. 10, 3, 313-331 321 
It is fairly clear that the picture which Skinner presents of poststructuralism in this first account is much the same as the conventional view of it outlined earlier in this article. As examples of individual thinkers who can be associated with this way of thinking, in both accounts Skinner cites the names of Roland Barthes (sic), Michel Foucault, and especially Jacques Derrida. Skinner claims that it was Barthes and Foucault who jointly announced the death of the author', in the 1950s and 1960s, 'thereby burying the time-honoured dwelling place of motives and intentionality' (Skinner, 2002c, pp. 90-91; 2002d, p. 117). However, in his opinion, 'by far the most damaging campaign' challenging the claim that when interpreting texts it is necessary to take account of the intentions of the author, 'was opened in the late 1960s and early 1970s' by the 'leading iconoclast' of poststructuralist philosophy, Jacques Derrida (Skinner, 1985, pp. 7-8). In The Return of Grand Theory, Skinner attributes to Derrida the view that we can 'never have enough authority to privilege any one interpretation' of a text 'over another' (Skinner, 1985, pp. 7-8). He also argues that according to Derrida the hermeneutic enterprise as it is traditionally understood, the aim of which is to seek 'the truth' in relation to the meaning of a text (it being assumed that texts do possess such a meaning, which is given to them by their authors, and that if it is to be successful the hermeneutic enterprise must, therefore, have at least something to do with authors and their intentions) is 'actually a mistake' (Skinner, 1985, p. 8). This is another feature which is common to both of Skinner's accounts of poststructuralism. For this was also Skinner's understanding of Derrida's position 3 years later in his 'Reply to My Critics'. There Skinner states that Derrida 'argues for the irrelevance of intentionality to communicable meanings' and that he 'has emphasized' that there are good reasons for 'abandoning all talk about intentionality' when interpreting the meaning of texts (Skinner, 1988, pp. 338 fn 171, 280).

It is clear from these remarks that Derrida's approach to hermeneutic understanding, as understood by Skinner in 1985, and Skinner's own approach, are mutually incompatible with one another. The one affirms what the other denies. According to this first account, both Skinner and Derrida are committed to the view that hermeneutic understanding has to do with the interpretation of texts, even if they understand the concept of interpretation differently. In Skinner's view however, whereas his own methodology rests upon the principle of authorial intentionalism and the pursuit of objective truth, that of Derrida does not. Thus, in The Return of Grand Theory Skinner emphatically rejects what he takes to be Derrida's methodological approach and, by implication, that of poststructuralism more generally.

According to Skinner's first account, there are both similarities and differences between his own methodological position and that of Derrida and poststructuralism. On this occasion, Skinner thought of himself as being in agreement with Derrida about some things. One of these is the belief that hermeneutic

322 (C) 2011 Macmillan Publishers Ltd. 1470-8914 Contemporary Political Theory Vol. 10, 3, 313-331 
understanding has to do with the interpretation of texts. On the other hand, though, he thought of himself as disagreeing with poststructuralists about others. In particular, although he and they were both interested in doing the same thing, namely the interpretation of texts, nevertheless they had quite different views regarding the issue of what this involves. They disagreed over the meaning of the concept of 'interpretation', as well as over the issue of how the task of interpretation ought to be carried out. Or rather, more accurately, Skinner had a definite view of what this method ought to be, whereas, in his opinion Derrida and other poststructuralists denied that there is such a method at all.

If the beliefs associated with Skinner's first account of poststructuralism are formulated in the terminology of the present article then it can be said that he associates poststructuralism with two basic principles. The first is that poststructuralists do not clearly distinguish between the interpretation and the appropriation of texts. On the contrary they identify the two. The second is that they are advocates of the appropriation and not the interpretation of texts, as he understands the term, and indeed as it is used here. Thus, in Skinner's view the understanding which poststructuralists have of the notion of 'interpretation' is quite different from his own. Skinner states that poststructuralists like Derrida have a certain attitude towards the interpretation of texts which he considers to be questionable, as it ignores completely the intentions of the author and has no interest at all in seeking the truth so far as the meaning of a text is concerned. By contrast, in this first account of poststructuralism Skinner was committed to the interpretation and not to the appropriation of texts although, like his poststructuralist opponents, he did not himself differentiate between these two notions. So far as Skinner was concerned in The Return to Grand Theory, the only legitimate way in which to read a text is to interpret it. Skinner suggests there that the sole aim of the readers of texts ought to be interpretation and that the appropriation of texts is not a legitimate activity at all. Skinner's first account is, therefore, based on monist rather than dualist assumptions.

\section{Interpretation, Appropriation and Deconstruction}

Before turning to consider Skinner's second account of Derrida and of poststructuralism, in this section I will offer some criticisms of his first account. The above remarks about Skinner's interpretation of the views of Derrida and poststructuralism raise the question of whether Skinner was right in the 1980s to interpret Derrida as someone who espoused the principles of 'anything goes!' and 'the death of the author' as principles of hermeneutic understanding? Again employing the terminology introduced earlier, we may ask whether Skinner's claim that Derrida was in effect an advocate of the appropriation of texts and not their interpretation was justified? This is a contentious issue, and one which 
has been much discussed by scholars with an interest in Derrida's work. There is not sufficient space here to give it the attention which it deserves. Suffice it to say that there are a number of reasons for thinking that the interpretation of Derrida's views in Skinner's first account is open to criticism.

I argued earlier that the picture of poststructuralism presented above does not fit accurately the views of some poststructuralist philosophers, especially Foucault and Deleuze. Neither of these two thinkers rejected the notion of interpretation out of hand. However, the same could also be said about Jacques Derrida. Derrida is, of course, associated with the notion of 'deconstruction', and the deconstructive reading of texts. We might ask, therefore, how the idea of deconstruction is related to those of interpretation and appropriation? Is the activity of deconstruction fundamentally different from that of both interpretation and appropriation - a third, independent form of reading in its own right? Or alternatively can the notion of deconstruction be reduced to either one or the other of the notions of interpretation and appropriation - and, if so, which one?

Now if the picture of poststructuralism presented earlier, and endorsed in Skinner's first account of it, is an accurate one; and if, further, there is no doubting Derrida's credentials as a 'poststructuralist' philosopher; it necessarily follows that Derrida was an advocate of appropriation and not of the interpretation of texts. According to this reading of Derrida, his approach is indeed diametrically opposed to that of Skinner. On the other hand, however, as more than one commentator has noted, there is empirical (textual) evidence to support the view that Derrida rejected both the principle that 'anything goes!' and that of 'the death of the author' (Norris, 1982, pp. 21-22, 43-44, 59-60, 138-140, 173; 1983, pp. 20, 113, 139, 219; Culler, 1983, pp. 131-132; Wood, 1987, pp. 176-177; Burke, 2008 [1992], pp. 133-144). Thus, for example, in a piece significantly entitled 'Toward an Ethic of Discussion', which Derrida appended to Limited Inc in 1988 (but which alludes to an earlier work, $O f$ Grammatology (1967), in which the same view was expressed), Derrida states explicitly that when interpreting texts one must pay close attention to the 'context' within which they were written (Derrida, 1976 [1967], p. 158; 1988b, pp. 111-154). According to Derrida, this includes noting the intentions of the author, 'otherwise one could indeed say just anything at all and I have never accepted saying, or encouraging others to say, just anything at all' (Derrida, 1988b, pp. 144-145). In this piece Derrida associates the principle that 'anything goes!', or the view that when interpreting a text one can say 'just anything at all', with epistemological anarchism, or with an attitude which he characterizes (negatively) as that of a 'skeptic-relativist-nihilist' (Derrida, 1988 b, p. 146). In response to his critics, however, Derrida explicitly denies that such a view could legitimately be attributed to him (Derrida, 1988b, pp. 146-147). 
Although Derrida does not employ the terminology introduced here, nevertheless it is possible to express his approach to hermeneutic understanding using that terminology. If one does so then it is arguable that Derrida associates deconstruction, or the deconstructive reading of texts, with the notion of interpretation and not with that of appropriation. On this reading of Derrida's views (which I offer as an interpretation of them) the aim of a deconstruction of a text is indeed to 'get at' a meaning which is assumed to be, not the product of the creative activity of the reader, or something which is added to the text by the reader in the act of reading, but rather a meaning which lies already there in the text itself 'waiting', as it were, to be discovered although of course, in Derrida's opinion, whether or not a particular interpretation of a text has achieved this is sometimes (perhaps always) open to doubt.

The difference between this view and the more traditional approach to hermeneutic interpretation advocated by Skinner is that Derrida does not identify the meaning of a text with the stated intentions of its author. Like the advocates of psychoanalytic literary criticism, Derrida accepts that authors might not have full, self-conscious control over the texts which they write. Nor, therefore, do they possess a privileged insight into their meaning. Consequently, when one is interpreting a text in order to discover or 'get at' its meaning, Derrida's view is that it will sometimes (perhaps always) be necessary to go beyond the intentions of its author, even while taking those intentions into account. For, of course, one could not argue that authors have failed to achieve their own goals, or have some how contradicted their own intentions, without first making an effort to establish what those intentions were. Far from completely setting aside the intentions of the author, therefore, deconstruction as Derrida understood it places the intentions of the author at the very heart of the hermeneutic enterprise, while also displacing them. From being the sole focus of interest, the intentions of the author become, for Derrida, just one of the things which the hermeneuticist must take into account when interpreting a text. As Derrida himself puts it, in a well-known passage cited by almost all of the commentators who discuss this issue, for those who embrace this way of thinking about hermeneutic understanding 'the category of intention will not disappear; it will have its place, but from that place it will no longer be able to govern the entire scene and system of utterance' (Derrida, 1976 [1967], p. 158; repeated at Derrida, 1988a, p. 18).

According to this interpretation of Derrida's approach to hermeneutic understanding, Derrida never endorsed either the principle that 'anything goes!' or that of 'the death of the author'. However, if this interpretation is accepted, it follows either that Derrida's deconstructive approach to the reading of texts should not be considered to be authentically 'poststructuralist' as it does not conform to the widely accepted account of poststructuralism 
outlined earlier, or alternatively (if we think this is absurd), that this conventional view of poststructuralism, endorsed by Skinner in The Return to Grand Theory, is inaccurate. It is not at all clear, therefore, that the critique of Derrida and of poststructuralism, which Skinner advances in The Return of Grand Theory is valid. Indeed it is arguable, and has been argued, that Derrida explicitly rejected the views, which Skinner's first account attributes to him.

\section{Skinner's Second Engagement with Poststructuralism}

Skinner's second account of poststructuralism, formulated in his 'Reply to My Critics' in 1988, although sharing a number of features associated with the first, is also different from it in a number of significant respects (Skinner, 1988, 2002d). The most significant difference is that Skinner came to accept that there is more than one legitimate way to read a text. Having formerly advocated a monist position, he came to embrace a dualist one. For example, he states there that he has no quarrel at all with those who advocate a different approach to the reading of texts from his own - that is, those who are not interested in interpretation. As Skinner put it, alluding to the views of Derrida, who again he took to be representative of the poststructuralist position, 'I remain unrepentant in my belief that, if we are interested in recovering the historical identity of texts, we are bound to interest ourselves in what their authors meant'. However, he goes on to concede, 'if we are interested in something quite different' [my emphasis], which he suggests we may legitimately be, for example 'in the study of their impact upon us, or in the free play of signifiers', then 'there may indeed be no good reason to trouble about intentionality at all' (Skinner, 1988, p. 273).

Employing the terminology introduced earlier, these remarks indicate that in 1988 Skinner had come to accept that there is indeed more than one valid way to read texts, even if there is still only one valid way to interpret them. Moreover Skinner did not then claim, as he had claimed earlier, that when reading texts the only issue to consider is that of the recovery of their meaning, as this is understood by their authors. Skinner came to accept, therefore, that his own methodological position was not necessarily in disagreement with that of poststructuralists such as Derrida after all. He acknowledged that he and they were not necessarily doing the same thing, namely interpreting texts, and in disagreement with one another over the issue of how this thing ought to be done. Rather, he and they might be doing quite different things. Hence, the issue of a possible disagreement between them as to how just one thing ought to be done need not arise.

Although of course Skinner did not then and does not now employ the terminology introduced earlier, nevertheless in his 'Reply' of 1988 he did 
distinguish explicitly between the concept of 'recovering the historical identity' of a texts, where, he argues, 'we are bound to interest ourselves in what their authors meant' and the quite 'different' concept of 'the study of their impact upon us, or in the free play of signifiers' (Skinner, 1988, p. 273). Thus, in his second account of poststructuralism Skinner did make something like the distinction between interpreting a text and appropriating it. Moreover, it follows from the fact that Skinner came to distinguish between these two concepts that, by the time he wrote his second 'Reply', he had indeed come around to the view that there is after all more than one way to read a text, even if there is only one way to interpret it.

Skinner's later remarks on this subject indicate that he was engaged in a process of rethinking, not only his understanding of poststructuralism, but also his own view of what is involved in the hermeneutic understanding of texts. To be more specific, in 1988 he came to appreciate that there is more to this activity than the interpretation of texts, and he came to accept that the interpretation of texts is only one legitimate form of reading amongst others. These later remarks might, therefore, be thought of as a concession towards the approach to hermeneutic understanding which Skinner associated with poststructuralism. What Skinner did not do in his 'Reply', however, is make the terminological distinctions which seem to me to be necessary if these later ideas are to be expressed in a satisfactory manner. The distinctions which I have made between the 'reading', the 'interpretation' and the 'appropriation' of texts are intended to address this issue.

I will conclude this discussion of Skinner's second account of poststructuralism by saying something about the most recent pronouncements, which he makes about this issue in his Regarding Method, published in 2002. In this text Skinner maintains that it was in the 1950s and 60s that Derrida 'began to argue that the very idea of textual interpretation is a mistake', and that 'there are no such readings' (that is, 'interpretations'), 'to be gained' (Skinner, 2002c, pp. 90-91). He also repeats his earlier suggestion that for Derrida 'it is an error to suppose that we can ever arrive unambiguously at anything recognizable as the meaning of a text (Skinner, 2002c, pp. 90-91)'. These remarks are, of course, themselves ambiguous in meaning. They might be taken to imply that, as Skinner understood him, Derrida held that it makes no sense at all to talk about the meaning of a text, For there is no such thing. Texts just do not have the one (unitary) meaning which they are assumed to have by advocates of the traditional approach to hermeneutics. Rather, they have a plurality of meanings - perhaps as many meanings as they have readers. Such a reading of Skinner's understanding of Derrida would be consistent with the first account which Skinner offers of Derrida's views referred to earlier.

Alternatively, however, this assertion might also be taken to imply (and arguably amounts to the same thing in practice) that, in Skinner's view, Derrida 
held that although it does make sense to talk about the meaning of a text, nevertheless the interpreters of texts can never be certain or even confident that their efforts to uncover this meaning have been successful. The example which Derrida uses to illustrate this point, which is also discussed by Skinner, is that of the assertion 'I have forgotten my umbrella' written on a scrap of paper found amongst Nietzsche's papers after his death (Derrida, 1978; Skinner, 2002c, p. 93; 2002d, pp. 121-122). Interestingly, Derrida writes about this example as if, like Skinner, he too endorses the principle of 'authorial intentionalism'. The point he makes in relation to these words is that, assuming that it was indeed Nietzsche who wrote them, although it is clear what the words themselves mean, nevertheless it may not now be possible in practice for us to recover what Nietzsche's intentions were when he wrote them - what his reasons were for writing them. As Skinner would put it, it may not now be possible in practice to establish what Nietzsche 'meant by' writing them (Skinner, 2002c, p. 93).

At first sight, it is not clear which of these two interpretations of Skinner's statement is correct, that is to say which of the two views just mentioned he wished to attribute to Derrida, although the first view is more consistent with Skinner's earlier account of poststructuralism than the second. Indeed, if Skinner's intention when he made the remark cited above was to interpret Derrida in the second way and not the first, then it is arguable that this significantly decreases the intellectual distance between his own methodological position and that of Derrida as he then understood him.

However, for present purposes, what really matters here is that when he made this assertion in 2002 Skinner's understanding of Derrida's position was significantly different from that presented in The Return of Grand Theory in 1985, though much the same as that endorsed in his 'Reply' of 1988. Earlier, Skinner had maintained that the difference between his own methodological approach and that of Derrida is not that he is an advocate of the interpretation of texts, whereas Derrida argued that we should do something else with them. Rather, he had claimed that the difference between himself and Derrida was that although both of them advocate the interpretation of texts, nevertheless they disagree about what this means, and therefore also about how the act of interpretation should be carried out. In 2002, however, Skinner's view of the relationship which exists between his position and that of Derrida was different. To be more specific, in Regarding Method Skinner indicates that although his own views had not changed, nevertheless his understanding of those of Derrida had. Derrida is now presented as holding that 'the very idea of textual interpretation is a mistake' (Skinner, 2002c, pp. 90-91). According to Skinner's revised judgment, then, whatever Derrida advocated it should no longer be said to be the interpretation of texts. Skinner suggests here that if we wish to adequately understand the relationship which exists between his own methodological position and that of Derrida it is necessary for us to formulate 
a conceptual distinction between the idea of interpreting texts on the one hand, and that of doing something else with them on the other. He thinks of himself as an interpreter of texts, and of Derrida as someone who does something else with them. Skinner does not, however, tell his readers what that something else is. He does not introduce the terminology, which in my view is required in order to formulate this distinction clearly. Again, the vocabulary which I have introduced in the present article is intended as a response to this suggestion.

To summarize, a comparison of the first account of Derrida advanced by Skinner in The Return of Grand Theory in 1985 and the second account set forward in his second 'Reply to My Critics' and in his Regarding Method indicates that the difference between the two is that Skinner came to the view that Derrida's poststructuralist approach to the reading of texts should not be dismissed out of hand because of its adherence to the principles of 'anything goes!' and 'the death of the author'. In his second account of poststructuralism, Skinner indicates that there is a need to distinguish between those, like Derrida, who advocate an approach to the reading of texts based on these two principles and those who choose to read texts in a different way, seeking to establish their meaning by considering inter alia the intentions of their authors. According to Skinner's later engagement with poststructuralism, each of these approaches to the reading of texts is legitimate. Formulating this shift of position in the terminology of the present article, we may say that, from earlier claiming that there is only one way to read texts, namely to interpret them, Skinner moved on to embrace the significantly different position that texts can legitimately be read in different ways, even though there is only one valid way to interpret them. Unlike his first account of poststructuralism, then, Skinner's second account is not monist, but dualist. As such, it might be associated with an attempted (though partial) rapprochement on Skinner's part between his own methodological position and that which he associates with poststructuralism.

\section{Conclusion}

In this article I have attempted to do two things. The first was to introduce the conceptual distinctions between the 'reading', 'interpretation' and the 'appropriation' of texts which, quite apart from any consideration of the views of either Quentin Skinner or those associated with poststructuralism, I consider to be a fruitful one for historians of ideas and students of the history of political thought. The second was to suggest that these distinctions are especially useful for anyone who is interested in understanding poststructuralist philosophy and its approach to problems of hermeneutics, in comparison with that advocated by Skinner. It is commonly thought that these two ways of thinking about hermeneutics are diametrically opposed to one another, indeed 
incompatible. If Skinner's approach is right then that advocated by poststructuralists must be wrong, and vice versa. Deploying these terminological distinctions, I have argued that the theoretical distance which exists between the views of Skinner and those advocated by poststructuralists is not as great as might be supposed.

\section{Note}

1 I am indebted to David Bell for this reference to Deleuze. In addition to the work of Ricoeur, the concept of appropriation is employed by Ian Fraser in Fraser (1997). It is also employed, in much the same sense, in Burns and Fraser (2000, pp. 17-18). I make the conceptual distinction between readings, interpretations and appropriations in Burns (2008, pp. 70-71, 92, 110).

\section{References}

Abrams, M.H. (1991) Doing Things with Texts: Essays in Criticism and Critical Theory, New York: Norton.

Barthes, R. (1977 [1968]) The death of the author. In: Image-Music-Text, Translated by S. Heath, London: Fontana, pp. 142-148.

Booth, W. (1979) Critical Understanding: The Power and Limits of Pluralism. Chicago, IL: University of Chicago Press.

Boundas, C. (2005) The art of begetting monsters: The unnatural nuptials of Deleuze and Kant. In: S.H. Daniel (ed.), Current Continental Theory and Modern Philosophy. Evanston: Northwestern University Press, pp. 254-280.

Burke, S. (ed.) (2008 [1992]) Doubling the text: Intention and its other. The Death and Return of the Author, 3rd edn. New York: Columbia University Press, pp. 133-144.

Burns, T. (2008) Political Theory, Science Fiction and Utopian Literature: Ursula K. Le Guin and the Dispossessed. Columbia University Press, Lanham, MD: Lexington Books.

Burns, T. and Fraser, I. (2000) Introduction: An historical survey of the Hegel-Marx Connection. In: T. Burns and I. Fraser (eds.), The Hegel-Marx Connection, London: Palgrave, pp. 1-33.

Clarke, C. (2009) Paths between positivism and interpretivism: An appraisal of Hay's via media. Politics 29(1): 28-36.

Cook, D. (1991) Rereading Gadamer: A response to James Risser. In: H.J. Silverman (ed.), Gadamer and Hermeneutics, London: Routledge, pp. 106-118.

Culler, J. (1983) On Deconstruction: Theory and Criticism after Structuralism. Ithaca, NY: Cornell University Press.

Deleuze, G. (1990) The Logic of Sense. New York: Columbia University Press.

Deleuze, G. (1995) Letter to a harsh critic. In: Negotiations: 1972-1990, Translated by M. Joughin. New York: Columbia University Press, pp. 3-12.

Derrida, J. (1976 [1967]) That dangerous supplement. In: Of Grammatology, Translated by G. Chakrovorty Spivak, Baltimore: Johns Hopkins University Press, pp. 141-164.

Derrida, J. (1978) I have forgotten my umbrella. In: Spurs: Nietzsche's Styles, Translated by B. Harlow. Chicago, Il: University of Chicago Press, pp. 123-143.

Derrida, J. (1988a) Signature, event, context. In: Limited Inc, Translated by S. Weber, J. Mehlman and A. Bass. Evanston, IL: Northwestern University Press, pp. 1-24.

330 (C) 2011 Macmillan Publishers Ltd. 1470-8914 Contemporary Political Theory Vol. 10, 3, 313-331 
Derrida, J. (1988b) Afterword: Toward an ethic of discussion. In: Limited Inc, Translated by S. Weber, J. Mehlman and A. Bass. Evanston, IL: Northwestern University Press, pp. 111-154.

Feyerabend, P. (1975) Against Method: Outline of an Anarchistic Theory of Knowledge. London: Verso.

Foucault, M. (1977) Prison talk. In: C. Gordon (ed.), Power/Knowledge: Selected Interviews and Other Writings 1972-1977. Sussex: Harvester Press, pp. 37-54.

Foucault, M. (1984) What is an author? In: P. Rabinow (ed.), The Foucault Reader: An Introduction to Foucault's Thought. Harmondsworth: Penguin, pp. 101-120.

Foucault, M. (1993 [1963]) The Birth of the Clinic: An Archaeology of Medical Perception. London: Routledge.

Fraser, I. (1997) Two of a kind: Hegel, Marx, dialectic and form. Capital \& Class 61: 81-106.

Hirsch Jr, E.D. (1967) In defence of the author. Validity in Interpretation, Chapter 1. New Haven, CT; London: Yale University Press, pp. 1-23.

Hirsch Jr, E.D. (1976) The Aims of Interpretation. Chicago, IL: University of Chicago Press.

Marsh, D. and Furlong, P. (2002 [1995]) A skin, not a sweater: Ontology and epistemology in political science. In: D. Marsh and G. Stoker (eds.), Theory and Methods in Political Science, 2nd edn. London: Palgrave, pp. 17-41.

Nietzsche, F. (1968) The Will to Power, Translated by W. Kaufmann and R.J. Hollingdale. New York: Vintage Books.

Norris, C. (1982) Deconstruction Theory and Practice. London: Methuen.

Norris, C. (1983) The Deconstructive Turn: Essays in the Rhetoric of Philosophy. London: Methuen.

Norris, C. (1987) Derrida. London: Fontana.

Ricoeur, P. (1976) Interpretation Theory: Discourse and the Surplus of Meaning. Fort Worth, TX: Texas Christian University Press.

Ricoeur, P. (1981) Appropriation. In: Hermeneutics and the Human Sciences: Essays on Language, Action, and Interpretation, Translated by J.B. Thompson. New York: Cambridge University Press, pp. 182-193.

Risser, J. (1991) Reading the text. In: H.J. Silverman (ed.), Gadamer and Hermeneutics, London: Routledge, pp. 93-105.

Skinner, Q. (ed.) (1985) Introduction: The return of grand theory. The Return of Grand Theory in the Human Science. Cambridge: Cambridge University Press, pp. 1-20.

Skinner, Q. (1988) A reply to my critics. In: J. Tully (ed.), Meaning and Context: Quentin Skinner and His Critics. Cambridge: Polity Press, pp. 231-288.

Skinner, Q. (ed.) (2002a) Meaning and understanding in the history of ideas. Visions of Politics, Volume I: Regarding Method. Cambridge: Cambridge University Press, pp. 57-89.

Skinner, Q. (ed.) (2002b) Interpretation, rationality and truth. Vision of Politics, Volume 1: Regarding Method. pp. 27-56.

Skinner, Q. (ed.) (2002c) Motives, intentions and interpretation. Vision of Politics, Volume 1: Regarding Method. Cambridge: Cambridge University Press, pp. 90-102.

Skinner, Q. (ed.) (2002d) Interpretation and the understanding of speech acts. Regarding Method. Cambridge: Cambridge University Press, pp. 103-127.

Wood, D. (1987) Beyond deconstruction? In: A. Phillips-Griffiths (ed.), Contemporary French Philosophy. Cambridge: Cambridge University Press, pp. 175-194.

Zizek, S. (ed.) (2004) Taking Deleuze from behind. Organs without Bodies: On Deleuze and Consequence. London: Routledge, pp. 44-55. 